\title{
Informator, rozmówca, wspólnik. Obrazy relacji Antropologa z Innym
}

\section{Abstract}

\section{Informant, Interlocutor, Partner. Images of the Anthropologist's Relationships with the Other}

The goal of this paper is a presentation of images of relationships between an anthropologist and the Other based on the three main paradigms (realistic, interpretative, processual) defining epistemology and methodology of anthropological fieldwork. In the first, the Other is understood as an informant - a person with whom the anthropologist has a privileged cognitive and moral position. In the second, the Other is presented as an interlocutor who gains an equal moral position, though not epistemological. In the third one, both are presented as entities with exactly the same epistemological and moral status, which metaphorically reflects the figure of the Other as an accomplice. In the end, I describe situation from my fieldworks among the E'ñepá Indians from Venezuelan Amazonia, as an example of processual changes in my image of the relationship between Anthropologist and Other.

Keywords: fieldwork, relationship between Anthropologist and Other, epistemology, ethics, paradigm, cultural anthropology

W niniejszym artykule opisuję trzy modele konceptualizowania, przedstawiania i opisywania relacji, jakie zachodzą pomiędzy Antropologiem a Innym w trakcie antropologicznych badań terenowych. Ramę koncepcyjną dla ich opisu stanowi model trzech paradygmatów badawczych we współczesnej antropologii kulturowej. W tekście najpierw przedstawię owe paradygmaty (realistyczny, interpretatywny, procesualny), następnie opiszę trzy modele obrazów relacji poznawczej oraz relacji etycznej zachodzącej między Antropologiem i Innym, by na koniec przyjrzeć się procesowi przekształcania tychże obrazów w czasie wieloletnich 
wyjazdów badawczych na przykładzie moich badań terenowych wśród Indian E'ñepá w wenezuelskiej Amazonii.

Zarówno Antropolog, jak i Inny będą tu rozumiani jako figury symbolizujące to, co dzieje się pomiędzy realnymi osobami (badaczem a ludźmi, z którymi pracuje) w trakcie procesu antropologicznego poznania. Antropolog to człowiek, który inicjuje relację z innymi ludźmi (konceptualizowanymi, doświadczanymi i przedstawianymi przez Antropologa jako Obcy) w celu poznania ich sposobów bycia w świecie. Nieistotne przy tym są jego motywy - te, jak wiemy, mogą być różne (od czysto poznawczych do czysto pragmatycznych). Ważne jest, że impuls poznawczy wychodzi od Antropologa i że jego naczelnym celem jest poznanie Innych (co nie wyklucza realizacji innych celów, np. politycznych czy społecznych). Z kolei Inny to osoba, z którą Antropolog czuje się obco i nie rozumie jej sposobu życia. To przeżycie Antropologa wyznacza obcość Innego, dyskomfort, jaki przeżywa badacz w interakcjach z Innym, buduje doświadczenie obcości. Im więcej dyskomfortu, w większej liczbie wymiarów codzienności, tym odczucie obcości większe. Dlatego też doświadczanie obcości jest relatywne i kontekstowe - zmienia się w zależności od historii indywidualnych i danej geertzowskiej „wiedzy lokalnej”. W badaniach antropologicznych także zmieniają się jej wyznaczniki. Kilkadziesiąt lat wcześniej (do lat 70. XX w.) Inny był odnajdywany głównie za pomocą wyznaczników geograficznych - dzięki swojemu oddaleniu przestrzennemu i kulturowemu - w światach społeczności pozaeuropejskich, kultur etnicznych czy ludowych. W wieku XXI Inny jest doświadczany także i w świecie Antropologa - za ścianą, w drugiej dzielnicy, po drugiej stronie monitora. Niezależnie jednak od tego, gdzie umiejscawiany jest Inny - jego podstawowa, konstytutywna cecha nie ulega zmianie: dla Antropologa jest on zawsze obcy i niezrozumiały.

\section{Trzy paradygmaty w antropologii}

Ramą koncepcyjną dla przedstawienia typów obrazów relacji pomiędzy Antropologiem a Innym jest model trzech paradygmatów badawczych tworzących współczesne oblicze epistemologiczne i metodologiczne antropologii kulturowej (etnologii). Model ten jest zaproponowaną przeze mnie propozycją uporządkowania rozwoju teoretycznego dyscypliny (zob. Buliński 2013, 2014: 97-100, 2018: 55-58), na razie w formie przyczynku, którego rozwinięcie wymaga osobnego opracowania.

Według tej propozycji we współczesnej antropologii kulturowej (pojmowanej po kuhnowsku - jako społeczność badaczy) obecne są trzy główne paradygmaty badawcze, które określam jako realistyczny, interpretatywny i procesualny ${ }^{1}$. W za-

1 W polskiej literaturze spotykane są ich różne określenia. Paradygmat realistyczny jest określany mianem pozytywistycznego, interpretatywny miejscami występuje jako symboliczny, 
leżności od tradycji badawczych i kolei historycznych różna jest ich powszechność i siła oddziaływania w krajach świata (sytuacja antropologii anglosaskiej jest odmienna od antropologii japońskiej czy hinduskiej). W polskiej etnologii wydaje się, że najbardziej rozpowszechniony jest paradygmat realistyczny, nieco mniej popularny jest paradygmat interpretatywny, zaś najmniej - paradygmat procesualny. Poniżej przedstawię skrótową charakterystykę tych trzech paradygmatów.

U podłoża paradygmatu realistycznego leży epistemologia realistyczna (pozytywizm). Antropolog zakłada, że może opisać i wyjaśnić sposób życia Innego za pomocą narzędzi poznawczych (technik badawczych w rodzaju wywiadu czy obserwacji uczestniczącej oraz schematów badawczych w rodzaju koncepcji wzorów kulturowych czy systemu społecznego). Badania terenowe są metodycznym zbieraniem faktów, możliwie ściśle określonym i kontrolowalnym. Niezrozumiałe i obce dla antropologa fakty są wyjaśniane dzięki teoriom. Przykładem jest tu funkcjonalizm we wszystkich swoich wydaniach (od Bronisława Malinowskiego poprzez Maxa Gluckmana aż po „wczesnego” Clifforda Geertza czy Maurice’a Godeliera). Metaforycznie paradygmat realizmu oddaje obraz Antropologa jako obserwatora, którego uwaga jest skupiona na narzędziach obserwacji (ich dokładności, precyzyjności, obiektywności itp.) oraz na trosce, aby sytuacja badawcza była pozbawiona „zakłócających” ją czynników (dążenie do usuwania czynników zaburzających obiektywne ujęcie danego zjawiska, takich jak np. sympatie bądź antypatie Antropologa wpływające na końcowe rezultaty).

U podłoża paradygmatu interpretatywnego leży epistemologia konstruktywistyczna. Antropolog zakłada, że może zrozumieć sposób życia Innego za pomocą narzędzi hermeneutycznych (opisów gęstych, analiz tubylczych kategorii itp.). Zdaje sobie jednak sprawę, że będzie to zawsze tylko interpretacja działań i wypowiedzi Innego. Badania terenowe polegają na uczestnictwie w wydarzeniach, rozmowie z Innymi i odkrywaniu znaczeń, jakie im nadają poszczególni aktorzy społeczni. Przykładem może tu być tzw. antropologia symboliczna w większości swoich wydań (od Victora Turnera poprzez Clifforda Geertza aż do Sherry Ortner). Metaforycznie paradygmat interpretatywny oddaje obraz Antropologa jako tłumacza. Jego uwaga jest skupiona na jak najbardziej poprawnym „przekładzie” kulturowego tekstu, tak aby jego sens został jak najmniej wypaczony.

U podłoża paradygmatu procesualnego leży epistemologia perspektywistyczna, wynikająca ze zwrotu ontologicznego ${ }^{2}$. Antropolog zakłada, że może poznać sposób życia Innego, „zderzając” z nim swój sposób życia. Antropolog za pomo-

natomiast największą różnorodność nazw posiada paradygmat procesualny, który jest nazywany postpostmodernistycznym, refleksyjnym, pragmatycznym czy postinterpretatywnym. Zob. np. Brodzki 2008; Clifford 1999, 2004; Hastrup 2008; Kaniowska 1999, 2009, 2011; Kempny 1994; Lubaś 2003, 2011; Marcus 2003, 2004; Rabinow 1999; Rakowski 2011.

2 Na temat konsekwencji epistemologicznych perspektywizmu zob. np. Viveiros de Castro 1998, 2004a, 2004b; zob. też: Buliński, Kairski 2011: 294-299. Na temat samego perspektywizmu zob. np. Buliński 2011, 2018; na temat zwrotu ontologicznego w antropologii zob. np. Holbraad, Pedersen 2017. 
cą samego siebie (a ściślej mówiąc - swojego doświadczenia) wytwarza metodą prób i błędów swoją intersubiektywną interpretację działań i wypowiedzi Innego. Badania terenowe polegają na uczestnictwie w życiu Innych w celu zdobycia jak najbardziej "gęstego" doświadczenia terenowego Antropologa (więcej: Buliński, Kairski 2011: 313-318), które ten cały czas reinterpretuje (przed badaniami, w trakcie badań i po nich). Przykładem mogą być prace Christiny Toren, Roya Wagnera czy Eduarda Viveirosa de Castro. Metaforycznie paradygmat procesualny oddaje obraz Antropologa jako narzędzia. Uwaga Antropologa jest skupiona na analizowaniu swojego doświadczenia $\mathrm{w}$ relacjach $\mathrm{z}$ Innymi i trosce, aby było ono możliwie jak najbogatsze i głębokie, tj. intensywne, zróżnicowane, powtarzalne i wielokrotne.

Te trzy paradygmaty określają, jak Antropolog postrzega sam siebie i Innego w procesie poznania antropologicznego. Oczywiście trzeba pamiętać, że jest to model i jako taki ma tendencje do upraszczania. Zdarza się, że w praktyce badawczej i pisarskiej poszczególnych antropologów, zwłaszcza analizowanej z perspektywy historycznej, można odnaleźć rozwiązania właściwe dla różnych paradygmatów (np. wystarczy popatrzeć na twórczość Victora Turnera, a nawet samego Bronisława Malinowskiego, nie mówiąc już o pracach współczesnych badaczy). Jeśli jednak spojrzeć od strony ilościowej ujętej w perspektywie historycznej, to da się zauważyć pewne regularności w stosowaniu przez konkretne społeczności antropologów rozwiązań właściwych dla danego paradygmatu (np. antropolodzy szkoły manchesterskiej częściej i w większym zakresie pisali prace w duchu paradygmatu realistycznego niźli pozostałych, natomiast polscy badacze z tzw. nowej etnologii polskiej byli bardziej skłonni do poruszania się w obrębie interpretatywizmu; zob. np. Buchowski 2012). Stąd też można podejrzewać, że istnieje coś takiego jak „nachylenie” paradygmatyczne, a więc tendencja obecna w społecznościach antropologów (grupach, zespołach, pokoleniach itp.) do stosowania w swoich studiach zbliżonych epistemologicznie rozwiązań.

Jak model trzech paradygmatów przekłada się na obrazy relacji Antropologa i Innego? Przyjrzyjmy się jej dwom podstawowym wymiarom: 1) obrazowi relacji poznawczej, jaka zachodzi w czasie wspólnego bycia Antropologa i Innego oraz 2) obrazowi relacji etycznej, jaka się tworzy pomiędzy nimi. Hasłową syntezę trzech paradygmatów oraz panujących w nich obrazów relacji Antropologa z Innym przedstawiam w tabeli 1. 
Tabela 1. Obraz relacji Antropolog - Inny w trzech paradygmatach

\begin{tabular}{|l|l|l|l|}
\hline & $\begin{array}{l}\text { Paradygmat } \\
\text { realistyczny }\end{array}$ & $\begin{array}{l}\text { Paradygmat } \\
\text { interpretatywny }\end{array}$ & $\begin{array}{l}\text { Paradygmat } \\
\text { procesualny }\end{array}$ \\
\hline Epistemologia & Realizm & Konstruktywizm & Perspektywizm \\
\hline Hasło & Fakt & Sens, znaczenie & Doświadczenie \\
\hline $\begin{array}{l}\text { Przykłady } \\
\text { antropologów }\end{array}$ & $\begin{array}{l}\text { B. Malinowski } \\
\text { E. Evans-Pritchard }\end{array}$ & $\begin{array}{l}\text { C. Geertz } \\
\text { S. Ortner }\end{array}$ & $\begin{array}{l}\text { R. Wagner } \\
\text { M. Strathern }\end{array}$ \\
\hline $\begin{array}{l}\text { Wizja badań } \\
\text { terenowych }\end{array}$ & $\begin{array}{l}\text { Badanie jako } \\
\text { zbieranie faktów }\end{array}$ & $\begin{array}{l}\text { Badanie jako } \\
\text { tworzenie } \\
\text { interpretacji }\end{array}$ & $\begin{array}{l}\text { Badanie jako } \\
\text { doświadczanie } \\
\text { sposobu bycia }\end{array}$ \\
\hline Obraz antropologa & Obserwator & Tłumacz & Narzędzie \\
\hline Obraz Innego & Informator & Rozmówca & Wspólnik \\
\hline $\begin{array}{l}\text { Wymiar poznawczy } \\
\text { relacji }\end{array}$ & $\begin{array}{l}\text { Tylko Antropolog } \\
\text { może poznać Prawdę } \\
\text { do Prawdy, ale } \\
\text { Antropolog może się } \\
\text { do niej zbliżyć }\end{array}$ & $\begin{array}{l}\text { Obaj mają swoją } \\
\text { jej potwierdzenia }\end{array}$ \\
\hline $\begin{array}{l}\text { Wymiar etyczny } \\
\text { relacji }\end{array}$ & $\begin{array}{l}\text { Dominacja moralna } \\
\text { Antropologa }\end{array}$ & $\begin{array}{l}\text { Równouprawnienie } \\
\text { moralne }\end{array}$ & Równość moralna \\
\hline
\end{tabular}

Źródło: opr. własne, Buliński 2018: 57.

\section{Kto co wie? Obrazy relacji poznawczej między Antropologiem a Innym}

W paradygmacie realistycznym Inny jest dostarczycielem faktów. Określany mianem informatora lub respondenta, jest konceptualizowany jako ktoś bierny, wystawiony na działania Antropologa. To Antropolog go bada, opisuje, rozważa, analizuje. Inny poddaje się badaniu i co najwyżej stawia mu opór (oczywiście z perspektywy Antropologa), nie chce „za darmo” stać się obiektem badań, więc rzuca kłody pod nogi badacza - nie dotrzymuje umów, nie rozumie pytań, reaguje zbyt emocjonalnie, oczekuje darów, uwagi, transportu itp. Jest tym niepokornym elementem relacji poznawczej, z którym Antropolog bierze się za bary, zmaga się i siłuje. Wszystko w imię poznania. I choć w wymiarze praktycznym prowadzenia badań etnograficznych Inny czasami jawi się jako osoba aktywna (gdy stawia opór zapędom poznawczym badacza lub poddaje wątki interpretacji faktów), to epistemologicznie stoi na słabszej pozycji - Antropolog dzięki nauce widzi więcej, wie więcej i potrafi przeniknąć uwarunkowania społeczne i kulturowe sposobu życia Innego. Natomiast Inny, według badacza, nie jest w stanie tego osiągnąć nie umie poprawnie wyjaśnić wszystkich aspektów wizyty i działań Antropologa, 
co najwyżej mgliście zdaje sobie sprawę, czym Antropolog się zajmuje i po co się zjawił w jego życiu. Słowem - to Antropolog wie lepiej.

Jeśli w antropologicznych tekstach pojawiają się opisy emocji w relacji między Antropologiem a Innym, dotyczą one głównie tego pierwszego - jego wdzięczności za pomoc, wgląd, umożliwienie, zaufanie itp. lub też jego gniewu, zawodu czy też znudzenia „opornymi” tubylcami. Inny wraz ze swymi uczuciami i emocjami jest ukryty na drugim planie, a na pierwszym pojawia się wtedy, gdy stanowi obiekt badań (gdy Jacques Lizot zechce „uczłowieczyć” Indian Yanomami w odpowiedzi na Srogich ludzi Napoleona Chagnona, pokaże z wielką drobiazgowością ich życie emocjonalne, własne zaś ukryje; zob. Lizot 1976). Rzadko też Inny występuje pod swoim imieniem lub nazwiskiem. O wiele częściej przywdziewa maskę uogólnionych figur - Trobriandczycy, Polacy, członkowie subkultur itp. Ludzie ukryci za słowami. Antropolog szybko pozbawia ich indywidualnych rysów. Konkretne osoby pojawiają się przy okazji podziękowań i podczas przytaczania ich wypowiedzi w formie cytatów. Nie ma tu miejsca na ich pytania, a zwłaszcza na ich zainteresowanie samym Antropologiem i jego światem.

W paradygmacie interpretatywnym Inny jest wyobrażany jako rozmówca, ktoś, z kim Antropolog wymienia słowa i znaczenia, uzgadnia sensy. Na pierwszy rzut oka wygląda to tak, jakby Antropolog zrezygnował ze swojej uprzywilejowanej pozycji poznawczej i oddał część władzy nad poznaniem Innemu, jakby końcowy rezultat był wynikiem ich współpracy. Antropolog wie, że tworzy tylko swoje interpretacje działań Innego, i wie, że obowiązkowo ma się w nich znaleźć miejsce dla jego wyobrażeń i sądów (wymóg uwzględnienia perspektywy podmiotowej). Pracowicie więc $z$ nim rozmawia, poznaje rozmaitość tubylczych punktów widzenia i przypadkowość (lokalność) własnej wiedzy. Mało tego! Zaczyna dostrzegać współautorstwo Innego, deklaruje, że finalnie efekt jego pracy (tekst naukowy, wyjaśnienie, teoria itp.) jest także wynikiem działań Innego. Próbuje więc wprowadzać go na strony książek, przyznając mu zaszczytne miejsce tłumacza czy głównego rozmówcy, którego perspektywa zaważyła na końcowej interpretacji Antropologa.

Warto jednak zauważyć, że w tym przypadku to nie tyle Inny staje się równoprawnym podmiotem poznawczym, ile Antropolog rezygnuje ze swej uprzywilejowanej epistemologicznie pozycji. W tekście Inny nie odgrywa aktywnej roli. Jego tubylcze koncepcje, jego sposoby rozumienia nie stają się rdzeniem poznawczym monografii, osią, wokół której krąży wysiłek poznawczy autora. Wprawdzie zostaje mu oddana toga partnerstwa antropologicznej wiedzy, lecz w naukowym tekście funkcjonuje tylko jako ktoś, kto współkształtował badacza w terenie, natomiast końcowa interpretacja życia danej grupy czy ludu jest w dalszym ciągu zasługą Antropologa. To Antropolog wyjaśnia świat Innego za pomocą swoich kategorii poznawczych i swoich koncepcji naukowych. W ostatecznym rozrachunku tubylcze modele poznawcze są włączone w obręb modelu Antropologa. 
W tym paradygmacie następuje zmiana opisów relacji emocjonalnych pomiędzy Antropologiem i Innym. Stają się zindywidualizowane i szczegółowe. Opis relacji Antropolog - Inny zyskuje status obowiązkowej części monografii antropologicznej, ponieważ rzuca światło na sposób uzyskania końcowej interpretacji. Ale nie jest to wcale najważniejsza i najobszerniejsza część monografii. Jest charakterystyczne, że gdy antropolog postanawia być zgodny z duchem tego paradygmatu, wtedy popada w skrajność - albo głównym przedmiotem książki czyni Innego (Rabinow 2010), albo też świadomie ustawia siebie pośrodku tekstu (Barley 1997). Zresztą to uwidocznienie Innego lub siebie w książce nie przynosi istotnych zysków poznawczych - takie prace nie oferują zdecydowanie pełniejszego wglądu w sposoby bycia Marokańczyków lub Dowajów niż klasyczne monografie etnograficzne à la Alfred Radcliffe-Brown. Natomiast rozwiązania pośrednie, w stylu geertzowskim, szybko osuwają się w cień paradygmatu realistycznego książki zaludniają uogólnieni Inni (Balijczycy czy Szerpowie) z wybranymi przez antropologa swymi imiennymi reprezentantami.

Z kolei paradygmat procesualny zakłada równość i symetryczność pomiędzy Antropologiem i Innym. Ma to być równość nie tylko moralna, etyczna, ale także epistemologiczna. Żaden z nich nie wie „lepiej”, np. dzięki temu, że stosuje metodę naukową, i żaden nie zajmuje uprzywilejowanej pozycji poznawczej. Każdy z nich stosuje swoje sposoby poznania, swoje kryteria prawdy (pragmatyczne) i działa zgodnie z nimi. Ich koncepcje prawdy, choć najczęściej rozbieżne, są w pełni prawomocne, gdyż potwierdzone przez ich doświadczenie. Inny testuje swoje sądy na temat Antropologa, Antropolog testuje swoje sądy na temat Innego. Obaj czynią to poprzez interakcję z tym drugim. Dla każdego z nich kryterium poprawności poznania jest skuteczność własnej praktyki. Jeśli Antropolog uczy się, poznaje, próbuje zrozumieć sposoby bycia w świecie Innego, robi to poprzez swoje działanie i obserwowanie, jak jego sposoby bycia w świecie kłócą się ze sposobami życia Innego. Antropolog nie jest więc kimś uprzywilejowanym epistemologicznie. Poznaje on Innego, oddziałując na niego, np. kręcąc film czy rozmawiając, i jest także obiektem poznania i oddziaływania ze strony Innego, np. będąc karmionym, pojonym alkoholem lub wypytywanym o swoje życie osobiste. Proces poznania drugiego zachodzi u obu stron i nie istnieją niezależne narzędzia, aby je ze sobą porównywać. Zachodzi jednak swego rodzaju „osmoza” poznawcza pomiędzy nimi. W obliczu problemów ze zrozumieniem sposobów bycia Innego Antropo$\log$ "pożycza” te elementy wiedzy tubylczej, które pojmuje, następnie przerabia je tak, aby zyskały kształt koncepcji humanistycznych, i dopiero w ich świetle jest w stanie sensownie zinterpretować to, czego doświadczył (np. tak się dzieje w perspektywizmie). Część kategorii poznawczych, których używa na poziomie swojego antropologicznego modelu, pochodzi od Innego. Można powiedzieć, że wyjaśnianie Antropologa jest w pewnym stopniu zapośredniczone przez wiedzę Innego. 
Opisy relacji emocjonalnych Antropologa z Innym nie mają odrębnego statusu w tekście. Są opisami sytuacji przeżytych przez Antropologa, a jego reakcje są równie ważnym źródłem wiedzy, jak reakcje Innego. Antropolog ujawnia swoje odczucia i emocje, wiedząc, że jego reakcje cielesne i emocjonalne dobrze obrazują odmienność sposobów życia Innego. Inny w tekście jest albo spersonalizowany w konkretnych sytuacjach, albo też świadomie uogólniony na potrzeby konwencji tekstu i jego perswazyjności.

\section{Kto co może? Obrazy relacji etycznej między Antropologiem a Innym}

W paradygmacie realistycznym Antropolog deklaruje równość moralną z Innym, której w praktyce badawczej nie przestrzega. Zadziwiająca jest rozbieżność pomiędzy mocą deklaracji, jakie wykwitły na polu antropologii (walka z etnocentryzmem, dyskryminacją i rasizmem), a łatwością, z jaką poszczególni badacze konstruowali w terenie relacje dominacji z innymi osobami. Przez historię dyscypliny ciągnie się plejada służących, tłumaczy, tragarzy, kucharek i pomocników - figur schowanych na zapleczu tekstów, nad którymi Antropolog (w swoim odczuciu) dominował, a nie partnersko z nimi współpracował. Lub też wykazywał irytację, gdy takiej dominacji mu brakło (jak Edward Evans-Pritchard wśród Nuerów). Oczywiście dość szybko sformułowano katalog działań nieetycznych w profesji antropologa. Badacz więc wie, iż nie powinien wykorzystywać Innych oraz działać na ich szkodę. Ale ten nakaz dotyczy podmiotu zbiorowego, czyli grupy, którą bada. Antropolog podejmuje swe etyczne zobowiązania wobec całej zbiorowości i czyni tak nawet nie wobec niej, tylko względem społeczności antropologów żyjącej w jego świecie. To oni go będą rozliczać. Etyczny wymóg dotyczy przede wszystkim wykorzystania rezultatów jego badań. W czasie badań, przed nimi i po nich Antropolog działa inaczej. Może wykorzystywać swoją wyższą pozycję społeczną, polityczną, ekonomiczną czy kulturową. I często tak robi. W przeszłości kontekst kolonialny wręcz do tego zachęcał - obraz Radcliffe'a-Browna siedzącego na werandzie, do którego przyprowadzani są andamańscy starcy, to archetypiczna sytuacja przewagi Antropologa. Nie powinno nas to dziwić - przecież jeżeli Antropolog wie lepiej („tubylcy nie znają prawdziwych przyczyn choroby”, „tubylcy wierzą w czary"), to łatwiej mu przyjąć taką samą postawę w zakresie moralności. Stąd już krok do paternalizmu i przekonania, że wie, co dla badanych ludzi jest lepsze, jak należy im pomagać i przed czym należy ich chronić. Wie lepiej od nich samych. W praktyce terenowej Antropolog ustawia się w pozycji osoby, która prezentuje poziom etyczny bardziej zaawansowany niż ten, jakim dysponuje Inny.

W paradygmacie interpretatywnym Antropolog deklaruje upodmiotowienie Innego. Wstydzi się swojej zaszłości kolonialnej (a później postkolonialnej) i próbuje się od niej odciąć. Inny zyskuje prerogatywy. W każdej kwestii jest pytany 
o zgodę - dotyczy to zdjęć, wykorzystania informacji, uczestniczenia w rytuałach. W wypowiedziach Antropologa staje się pełnoprawnym partnerem badań, który ma prawo do odmowy uczestnictwa w nich, do ochrony siebie i swojej społeczności, do potencjalnych korzyści z badań antropologa itp. Jest przy tym zastanawiające, że prawa Innego rozciągają się na badania terenowe i wykorzystanie ich rezultatu (książki, raportu itp.), ale nie dotyczą samego tekstu. Antropolog w tym paradygmacie nie godzi się na ingerencję Innego w swoim tekście. To pokazuje granice partnerstwa. Inny może być partnerem, ale tylko $\mathrm{w}$ ramach swojego świata - w świecie antropologa nadal nie ma dla niego miejsca i tam relacja dominacji trwa nadal, choć w ukryciu. Idea upodmiotowienia Innego jest w tym paradygmacie swego rodzaju „światopoglądem” dyscypliny, zawartym w kodeksach etycznych i wyznacznikach uczciwego postępowania (takich jak kodeks etyczny American Anthropological Association).

Nietrudno zauważyć, że ta postawa Antropologa jest światopoglądowym odwróceniem, antytezą postawy z paradygmatu realistycznego. I nakierowana ona jest przede wszystkim na Antropologa, nie Innego. Pytanie o zgodę, idea wywodząca się z tradycji filozofii europejskiej, czyli jakkolwiek by patrzeć - wiedzy lokalnej, ma przynieść pewność Antropologowi, nie Innemu, że oto nie sprzeniewierza się „światopoglądowi” swojej dyscypliny. Dziwnym trafem przestaje być ważne dla Antropologa, że proces uzgadniania i jego rozumienie różnią się znacznie w zależności od ludzi, kultur i ludów. I przeprowadzanie go wyłącznie na płaszczyźnie ustaleń słownych jest czasami przez Innego rozumiane i przeżywane zupełnie inaczej. Tak jakby uzyskanie formalnej zgody społeczności lokalnej na przeprowadzenie badań zwalniało od przestrzegania wymogów antropologicznego poznania - obowiązku przestrzegania perspektywy podmiotowej i opisywania zjawisk takimi, jakimi one są dla Innych. Podejrzewać można, że Antropolog pragnie, aby Inny okazał się swego rodzaju partnerem w badaniach terenowych, ponieważ wtedy zostaje okiełznana jego obcość. Partner bowiem to ktoś, z kim badacz chce osiągnąć ten sam cel. A więc jeśli Inny jest dla Antropologa partnerem (i sam słownie wyraża taką gotowość), wtedy obaj stają się moralnie podobni, obaj są w stanie współpracować i uzgadniać warunki tej kooperacji. Inny staje się podobny do Antropologa.

W paradygmacie procesualnym obraz relacji etycznej pomiędzy Antropologiem a Innym ulega zmianie. Obydwa podmioty są tu w takiej samej sytuacji moralnej. Każdy z nich ma swoje kryteria dobrego postępowania i żadna ze stron nie jest w stanie zaaplikować ich drugiej osobie. Inny i Antropolog stają się wspólnikami - biorą udział w tej samej sytuacji badań terenowych, ale każdy z nich inaczej ją pojmuje, kieruje się innymi motywami i przesłankami oraz realizuje odmienne cele. Nie ma tu mowy o partnerstwie. Jedyne, co ich łączy, to współudział. Jest to sytuacja równości moralnej. Obaj mogą (i często to robią) wykorzystywać drugą osobę do osiągania swoich korzyści. Obaj też mogą zwracać uwagę na odczucia wspólnika i powstrzymywać się od jego wykorzystywania. Żadna ze stron nie ma 
moralnego obowiązku przestrzegania dodatkowych norm etycznych ponad te, które stosuje w swoim życiu. W szczególności dotyczy to Antropologa - badania terenowe pod względem moralnym nie różnią się od jego życia pozazawodowego, codzienności w jego świecie. Dominacja i wykorzystanie są w nim na porządku dziennym, mogą mieć miejsce w rodzinie, związkach uczuciowych, pracy, relacjach handlowych itp. Antropolog w swojej codzienności ciągle jest wystawiony na ryzyko wykorzystania przez kogoś i zapewne sam też czasami wykorzystuje inne osoby. Sytuacja prowadzenia badań terenowych od strony moralnej niczego tu nie zmienia. Inny nie jest odmiennym typem człowieka, którego należy objąć protekcją i chronić przed złym wpływem Antropologa. Z obu stron stoją dojrzali ludzie, którzy działają, opierając się na swoim poczuciu moralności. I każde takie działanie może się okazać bolesne dla drugiej strony. Kodeksy etyczne profesji nie zabezpieczą Antropologa przed podejmowaniem trudnych, osobistych decyzji. I też mu w nich nie pomogą. W ostatecznym rozrachunku, w terenie czy poza nim, przy podejmowaniu moralnych wyborów każdy staje tylko wobec siebie, niezależnie od tego, czy wybory te dotyczą ludzi ze swojskiego, czy też obcego świata.

\section{Przekształcanie obrazów relacji Antropolog i Inny - przykład z własnych badań terenowych}

Powyżej przedstawiłem statyczny model, w którym obrazy relacji Antropologa i Innego zależą przede wszystkim od paradygmatu badawczego, w którego obrębie sytuuje się badacz i jego sposób myślenia. W tej części zajmę się zobrazowaniem wymiaru dynamicznego powyższego zjawiska. Sposób, w jaki badacz widzi siebie oraz ludzi, z którymi pracuje, nie musi być przecież niezmienny. Konstruowanie tego obrazu jest procesem, który zaczyna się na długo przed wyjazdem w teren, trwa zarówno w czasie prowadzenia badań, jak i po nich, a jego końcową formę poznać możemy w postaci tekstu naukowego. Nie pretenduję tu do przedstawienia całego tego procesu, gdyż jest to zadanie znacznie przekraczające ramy tego tekstu (zob. złożoność opisu samego powstawania wiedzy terenowej w antropologii w: Buliński, Kairski 2011: 319-329). W tym miejscu odwołam się do sytuacji z moich badań terenowych wśród Indian E'ñepás, która pokaże przeobrażenia mojej interpretacji obrazu relacji Antropolog - Inny.

3 Indianie E’ñepá (egzoetnonim to Panare) to grupa etnojęzykowa mówiąca językiem z karaibskiej rodziny językowej, żyjąca w wenezuelskiej Amazonii. Liczy sobie ponad 4500 osób, które dzielą się na trzy grupy regionalne: Indian E’ñepá zachodnich, środkowych i południowych (zob. Henley 1988, 1994). Badania prowadziłem wśród południowej grupy regionalnej tego ludu, żyjącej w dorzeczu rzeki Cuchivero i Ventuari, liczącej sobie około 1400 osób. E’ñepá to grupa o osadnictwie półnomadycznym z gospodarką opartą na kopieniactwie, łowiectwie i zbieractwie, o egalitarnej strukturze politycznej i z organizacją społeczną opartą na kognatycznych związkach pokrewień- 
Sytuacja dotyczyła wywiadu z Carlosem, jaki przeprowadziłem w czasie jednego z pierwszych wyjazdów w teren ${ }^{4}$. Carlos był jednym z trójki E’ñepá, którzy najdłużej pracowali jako nauczyciele w indiańskiej szkole. Stąd też moja ogromna chęć, aby poznać jego opinię na temat działania edukacji szkolnej wśród E’ñepá, którą współtworzył od ponad 15 lat. Sama rozmowa trwała ponad godzinę i była oparta na częściowo ustrukturyzowanym wywiadzie kwestionariuszowym, który - jak wtedy sądziłem - był mi niezbędny do prowadzenia badań terenowych i wywoływania danych etnograficznych. Tak jak mnie nauczono na studiach etnologicznych - w trakcie wywiadu posiłkowałem się notatkami i nagrywałem całość na dyktafon. Przed wywiadem byłem zarazem podekscytowany, jak i zagniewany. Z Carlosem próbowałem się umówić na tę rozmowę już od kilku dni, ale ciągle coś stało na przeszkodzie (lekcje, zmęczenie, polowanie itp.). Miałem wrażenie, że mnie zbywa. Pomimo tego, że codziennie się widywaliśmy i gawędziliśmy (byliśmy sąsiadami, mieszkałem w jego nowo budowanym domu), wydawało mi się, że Carlos najchętniej uniknąłby umówionej rozmowy. Z drugiej strony gonił mnie czas. Nieubłaganie zbliżał się termin, kiedy musiałem opuścić osadę. Bałem się więc, że pomimo stosunkowo dużej zażyłości z Carlosem nie przeprowadzę z nim wywiadu. Wreszcie przedostatniego dnia udało mi się doprowadzić do tego, że umówił się ze mną na konkretną porę późnego popołudnia (moment gdy dorośli odpoczywają). Czekałem pełen emocji. Ale o umówionej porze go nie było. A im dłużej nie pojawiał się w osadzie i im bardziej słońce zbliżało się do horyzontu, tym bardziej narastała moja złość i frustracja. Było dla mnie ewidentne, że Carlos mnie zlekceważył i nie dotrzymał umowy. Dodatkowo przepełniały mnie żal i irytacja na myśl o tym, że nie przeprowadzę wywiadu z jedną z osób, które uważałem za kluczowe dla interesującej mnie tematyki. Kiedy więc Carlos w końcu się pojawił, idąc wolnym krokiem, odczułem zarazem radość i złość. Co oczywiście usiłowałem przed nim ukryć. Skrzętnie podszedłem z notatnikiem i dyktafonem, zdecydowany tym razem nie dopuścić, aby sposobność wywiadu przepadła. Moja determinacja zadziałała (tak mi się wtedy zdawało) i usiedliśmy przed domem w blasku zachodzącego słońca. Po zapytaniu, czy nie będzie mu przeszkadzać nagrywanie rozmowy, i uzyskaniu zgody rozpocząłem upragniony wywiad. Jego rezultat mocno mnie rozczarował. Wywiad zawierał wiele pytań o program nauczania, metody dydaktyczne, miejsce szkoły w życiu Indian i inne kwestie związane $\mathrm{z}$ edukacją, jakie wyprowadziłem $\mathrm{z}$ dotychczasowych, znanych mi badań nad szkołą (głównie proweniencji socjologicznej i pedagogicznej, choć znałem także

stwa. Ich kontakt $\mathrm{z}$ wenezuelskim społeczeństwem narodowym jest ograniczony do handlu i szkoły. Moje badania dotyczyły miejsca i roli szkoły w świecie Indian (zob. Buliński 2018). Łącznie w latach 2001-2009 odbyłem siedem trzymiesięcznych wypraw badawczych (sumarycznie około roku w terenie).

4 Wszystkie imiona osób, z którymi pracowałem, zostały zmienione. Jest to moja decyzja podyktowana moim wyobrażeniem potencjalnych negatywnych skutków społecznych (zarówno w obrębie społeczności indiańskich, jak i w relacjach pomiędzy E’ñepá a członkami społeczeństwa narodowego Wenezueli), jakie mogłoby przynieść przytaczanie prawdziwych imion i nazwisk. 
prace z antropologii edukacji). Odpowiedzi Carlosa albo tylko potwierdzały mój obraz szkoły u E'ñepá, albo odbiegały od tematu - często nie odpowiadał na moje pytania i mówił o innych, doskonale mi znanych aspektach szkoły, np. narzekał na niedofinansowanie placówki oświatowej, lenistwo uczniów lub niechęć do współpracy z nim ich rodziców. Wywiad tak bardzo mnie zniechęcił, że po odsłuchaniu na długi czas odłożyłem jego transkrypcję. Po powrocie z tego wyjazdu terenowego byłem przekonany, że wywiad z Carlosem nie dał mi żadnych nowych informacji. To tyle w kwestii opisu samej sytuacji.

W powyższej relacji opisuję, jak postrzegałem (konceptualizowałem) siebie i Carlosa jako Antropologa i Innego na początku moich badań w roku 2002. Carlos był wtedy przeze mnie traktowany jako osoba, która posiada wiedzę na interesujący mnie temat i z której należy tę wiedzę wydobyć. Jadąc w teren i idąc na spotkanie z nim, miałem dobrze określony obraz tego, czym jest szkoła u Indian, jak ona działa i jakie aspekty jej funkcjonowania powinienem poznać. Nie zdawałem sobie z tego za bardzo sprawy, ale byłem przekonany, że wiem lepiej niż Carlos, co badam, i jak to, co badam, powinno wyglądać. Mój obraz rzeczywistości był „zawłaszczony” przez modele teoretyczne znane mi z książek oraz techniki badawcze nabyte w trakcie wykształcenia akademickiego. Nie było w nim zbyt wiele miejsca dla samego Carlosa. Przyjeżdżając do osady, miałem plan tego, co chcę robić. Planowałem wywiady z wybranymi osobami (nauczycielami, uczniami, członkami organizacji indiańskich, urzędnikami, sanitariuszami itp.), obserwowanie wybranych praktyk społecznych (np. lekcji czy zebrań). Na tym etapie rzeczywistość, której doświadczałem, interesowała mnie fragmentarycznie - ciekawiło mnie to, co - jak sądziłem - powinno mnie ciekawić. A więc to, co dotyczyło szkoły. Przyglądałem się więc wybranym fragmentom świata Indian E’ñepá programowi, nauczania, uczniom, lekcjom, nauczycielom itp. Ten sposób okazał się trudny emocjonalnie $\mathrm{z}$ dwóch powodów.

Po pierwsze dlatego, że wszystkie te działania przynosiły mizerne (jak wówczas myślałem) rezultaty badawcze. Uzyskiwałem wiedzę, która niewiele mi wyjaśniała. Tak jak w przypadku wywiadu z Carlosem. W świetle zdobywanej wiedzy szkoła wśród E’ñepá jawiła mi się jako gorsza wersja szkoły nowożytnej, czasami wręcz wyglądająca jak jej karykatura. Coś, co przypomina szkołę, ale nie działa jak szkoła. Jaki był więc sens jej istnienia dla Indian? Nie rozumiałem tego. To powodowało moje frustracje. Po drugie dlatego, że miałem odczucie, iż ciągle mierzę się z Innym, z jego niechęcią (rzeczywistą lub wyobrażoną), oporem Innego.

Zobaczmy teraz, jak tę samą sytuację zinterpretowałem kilka lat później, po czterech następnych pobytach badawczych wśród Indian E'ñepá. W ich trakcie zmieniłem swoje nastawienie badawcze oraz swój obraz tego, jak poznaję jako Antropolog i co się wydarza w moich relacjach z Innymi. Przede wszystkim zarzuciłem klasyczne wywiady etnograficzne. Przestałem też koncentrować się na szkole. Zamiast tego skupiłem się na małych wycinkach doświadczenia, niezaplanowanych rozmowach, krótkich wymianach zdań w czasie codziennych działań. 
Prócz tego zacząłem rozmawiać o historiach poszczególnych osób, rekonstruowałem historię osad, odtwarzałem koleje życia osób, które zostały indiańskimi nauczycielami. Skupiałem się na indywidualnych użyciach słów, kiedy i gdzie, w jakich kontekstach się pojawiają. Obserwowałem, ale teraz już nie szkołę, ale codzienność, i próbowałem budować wytłumaczenia sytuacji wydarzających się dookoła. Tych typowych dla mnie i tych, które odbierałem jako nietypowe. Innymi słowy - usiłowałem zrekonstruować tubylczą logikę, która rządzi całą otaczającą mnie rzeczywistością, a nie - jak uprzednio - tylko szkołą. A ponieważ doświadczany świat Indian E’ñepá okazał się inny (bazował bardziej na ciele i zachowaniach niż na wypowiedziach), stąd też główną techniką badawczą okazało się uczestniczenie w codzienności, zaś prowadzenie wywiadów dotyczyło rozmaitości znaczeń słów w języku eñepá.

Jak to wpłynęło na interpretację sytuacji wywiadu z Carlosem? Pamiętamy, że zniechęcony rezultatem wywiadu odłożyłem jego szczegółową transkrypcję na później. Zasiadłem do niej nastawiony sceptycznie, dobrze pamiętając swoje negatywne odczucia z roku 2002. Jakież było moje zdziwienie, gdy odsłuchałem tego, co się wtedy działo! Sam wywiad się nie zmienił - z głośnika płynęły moje naiwne pytania o szkołę oraz próby Carlosa, by na nie odpowiedzieć. Zmieniło się za to moje spojrzenie. Rzeczy, które wcześniej były dla mnie bez znaczenia, pomyłki Carlosa, jego przemilczenia i urwane zdania, odpowiedzi nie na temat, sposoby konstruowania zdania, wszystko to nagle stało się ważniejsze niż same odpowiedzi na moje pytania. A same pytania w ogóle przestały mieć znaczenie. Nagle odkryłem, że nagrywając wywiad z Carlosem, nieświadomie uwieczniłem dialog pomiędzy osobami pozostającymi w obrębie innych rejestrów poznawczych, pomiędzy osobami, które tylko pozornie rozmawiają o tym samym. Ja prowadziłem wywiad o szkole skonstruowany na podstawie tego, jak się postrzega i bada tę instytucję w społeczeństwach w kręgu kultur euroamerykańskich. Carlos w czasie wywiadu stosował wobec mnie praktykę słowną wykazującą cechy mowy rytualnej (dialogu ceremonialnego). To, co wcześniej traktowałem jako odpowiedzi na swoje pytania, teraz okazało się sposobem "narzucania” mi przez Carlosa swojej perspektywy doświadczania rzeczywistości oraz metodą „oswajania” mnie jako Innego. (Biali są dla niego niebezpiecznymi, drapieżnymi Innymi). Okazało się, że ponad połowa wywiadu dotyczyła tego, co było istotne dla Carlosa, i obejmowała wątki wybierane oraz rozwijane przez niego. A przypomnę, że wcześniej, w roku 2002, byłem pewien, iż to ja doprowadziłem do sytuacji wywiadu, ja zadawałem pytania i ja kontrolowałem interakcję. To, co z mojego ówczesnego punktu widzenia było wyłącznie zbieraniem informacji o funkcjonowaniu szkoły, zawierało w sobie wypowiedzi, które ze szkołą związane były tylko pośrednio, a dotyczyły sposobu widzenia (i odbierania) ludzi żyjących w tej osadzie oraz samego Carlosa. „Wywiad” okazał się sytuacją interakcyjną, której wcale nie kontrolowałem - choć tak mi się wydawało - i którą Carlos był w stanie ukierunkowywać w stronę, na 
której mu zależało (na temat samej analizy wywiadu z Carlosem jako mowy rytualnej zob. Buliński 2018: 269-281).

W powyższym opisie widać zmianę mojego postrzegania pozycji epistemologicznej mojej i Carlosa. Przede wszystkim zauważam, że jego modele interpretacyjne świata są równie użyteczne, jak moje. Wykorzystuję więc indiańskie kategorie poznawcze i schematy interpretacyjne (biali, obcy, krewni, wrogowie itp.) do tego, żeby lepiej zrozumieć sytuację, w której brałem udział. Inaczej mówiąc, tubylczy model poznawczy stał się częścią modelu poznawczego badacza. Dostrzegłem też, że interakcje, w których biorę udział, są procesami, które współtworzą obie ich strony - Antropolog i Inny. Dziś sądzę, że Carlos był w stanie kształtować nie tylko rozmowę ze mną, ale także i moje doświadczanie świata, wpływać na to, jak odbieram emocjonalnie jego samego i jak wobec niego postępuję. Wydaje mi się wręcz, że były to nie tyle rozmowy polegające na wymianie informacji pomiędzy dwoma osobami, ile bardziej praktyki społeczne nakierowane na osiąganie konkretnych efektów społecznych (np. zdobywania dóbr ze świata Białych).

Podsumowując, pierwszą interpretację wywiadu z Carlosem (początek badań) można przyporządkować do obrazu relacji między Antropologiem i Innym charakterystycznego dla paradygmatu realistycznego, natomiast drugą (koniec badań) do paradygmatu procesualnego. Dziś, z perspektywy czasu, mogę zaryzykować stwierdzenie, że obrazy Antropologa i Innego, jakie samoistnie tworzyłem przed badaniami, $w$ ich trakcie i po nich, przeobrażały się i zmieniały (i dalej zmieniają). Nie są one stałe. Niemniej jednak widać w nich pewną linię rozwoju podczas pierwszych pobytów $\mathrm{w}$ terenie o wiele łatwiej było mi spontanicznie budować wyobrażenia charakterystyczne dla paradygmatu realizmu, podczas gdy w czasie ostatniego wyjazdu przychodziło mi to znacznie trudniej.

Wydaje się, że ma to związek ze zmianą wyobrażania sobie przeze mnie, czym są badania terenowe. W pierwszym okresie wyobrażałem je sobie jako ciąg zaplanowanych działań. Plan badawczy określa rzeczy do wykonania - techniki badawcze, miejsca do odwiedzenia, ludzi do poznania itd., rezultaty takich działań, wywiady, obserwacje, spisy, zdjęcia, zestawy informacji. Napisany później tekst naukowy przedstawia rezultat badawczy, który jest wynikiem zaplanowanych działan - swego rodzaju zmagań badacza z rzeczywistością. Natomiast w drugim okresie zacząłem patrzeć na badania jako na ciąg przypadków. Oczywiście miałem swój plan, próbowałem go wykonać, ale moje rozumienie szkoły u E’ñepá powstało raczej w wyniku prób ogarnięcia niemożności jego realizacji. Plan badawczy był tylko drogą, swego rodzaju drabiną, po której wspinałem się do doświadczenia. Tak naprawdę moje badania terenowe były zestawem przypadkowych sytuacji, w których tylko czasami próbowałem wprowadzić porządek (wywołując część z nich, jak np. wywiady), lecz zdecydowana większość z nich to dzieło innych osób. Rzekłbym więc, że przeszedłem od wyobrażania sobie badań terenowych jako planu do myślenia o badaniach jako o przypadku. 


\section{Podsumowanie}

W niniejszym tekście zaprezentowałem trzy typy konceptualizowania relacji, jakie zachodzą pomiędzy Antropologiem a Innym w trakcie antropologicznych badań terenowych. Każdy z tych typów jest oparty na założeniach i sposobach myślenia charakterystycznych dla trzech paradygmatów badawczych we współczesnej antropologii kulturowej: realistycznego, interpretatywnego, procesualnego. Nawiązując do ich założeń, pokazałem, jak wygląda wymiar poznawczy i etyczny w każdym typie obrazu relacji Antropolog - Inny. Na koniec tekstu przybliżyłem proces przekształcania obrazów relacji Antropolog - Inny na przykładzie jednej sytuacji z moich własnych badań terenowych wśród Indian E’ñepá w wenezuelskiej Amazonii.

\section{Bibliografia}

Barley N.

1997 Niewinny antropolog. Notatki z glinianej chatki, przeł. E.T. Szyler, Warszawa.

Brodzki M. 2008 Antropologia: literatura - dialog - przekład, Wrocław.

Buchowski M.

2012 Etnologia polska. Historie i powinowactwa, Poznań.

Buliński T.

2011 Ludzie, zwierzęta i inne byty w świecie Indian Amazonii. Wstęp do perspektywizmu, w: A. Mica, P. Łuczeczko (red.), Ludzie i nie-ludzie. Perspektywa socjologiczno-antropologiczna, Gdańsk, s. 89-114.

2013 Nasze metodologiczne minimum. Rozwój metodologii w antropologii, wystąpienie konferencyjne na I Polskim Kongresie Antropologicznym, Polski Instytut Antropologii, Warszawa.

2014 Ruchoma wiedza terenowa. Perspektywa antropologii procesualnej, „Zeszyty Etnologii Wrocławskiej”, nr 2 (21), s. 97-116.

2018 Szkoła $w$ amazońskiej puszczy. Formy i znaczenie edukacji w społecznościach tubylczych na przykładzie Indian E’ñepá z Wenezueli, Gdańsk.

Buliński T., Kairski M.

2011 Wiedza terenowa $w$ antropologii: $w$ poszukiwaniu nowego wymiaru badań terenowych, w: T. Buliński, M. Kairski (red.), Teren w antropologii. Praktyka badawcza we współczesnej antropologii kulturowej, Poznań, s. 291-333.

Clifford J.

1999 O autorytecie etnograficznym, w: M. Buchowski (red.), Amerykańska antropologia postmodernistyczna, przeł. J. Iracka, S. Sikora, Warszawa, s. 123-159.

2004 Praktyki przestrzenne: badania terenowe, podróże i praktyki dyscyplinujące $w$ antropologii, w: M. Kempny, E. Nowicka (red.), Badanie kultury. Elementy teorii antropologicznej. Kontynuacje, t. II, przeł. S. Sikora, Warszawa, s. 139-179.

Hastrup K.

2008 Droga do antropologii. Między doświadczeniem a teorią, przeł. E. Klekot, Kraków. 
Henley P.

1988 Los E’ńepa (E’ñepá), w: W. Coppens (comp.), Los aborígenes de Venezuela, t. III, Caracas, s. 215-306.

1994 E'ñepá, w: J. Wilbert (ed.), Encyclopedia of World Cultures 7: South America, Boston, s. 264-267.

Holbraad M., Pedersen M.

2017 The Ontological Turn: An Anthropological Exposition, Cambridge.

Kaniowska K.

1999 Opis - klucz do rozumienia kultury, Łódź.

2009 Heurystyczna wartość wiedzy antropologicznej, w: A. Pomieciński, S. Sikora (red.), Zanikające granice. Antropologizacja nauki i jej dyskursów, Poznań, s. 19-41.

2011 Metoda etnograficznych badań terenowych i poznanie $w$ antropologii, w: T. Buliński, M. Kairski (red.), Teren w antropologii. Praktyka badawcza we wspótczesnej antropologii kulturowej, Poznań, s. 277-289.

Kempny M.

1994 Antropologia bez dogmatów - teoria społeczna bez iluzji, Warszawa.

Lizot J.

1976 El círculo de los fuegos. Vida y costumbres de los indios Yanomami, trad. J. Musto, Caracas.

Lubaś M.

2003 Rozum i etnografia, przyczynek do krytyki antropologii postmodernistycznej, Kraków.

2011 Więcej niż wiedza lokalna. W kierunku postinterpretatywnej koncepcji intensywnych badań terenowych, w: T. Buliński, M. Kairski (red.), Teren w antropologii. Praktyka badawcza we współczesnej antropologii kulturowej, Poznań, s. 29-66.

Marcus G.E.

2003 Użyteczność kategorii uczestnictwa w zmieniających się kontekstach antropologicznych badań terenowych, w: D. Wolska, M. Brodzki (red.), Clifford Geertz - lokalna lektura, przeł. J. Jaxa-Rożen, Kraków, s. 155-181.

2004 Wymogi stawiane pracom etnograficznym w obliczu ogólnoświatowej nowoczesności końca dwudziestego wieku, w: M. Kempny, E. Nowicka (red.), Badanie kultury. Elementy teorii antropologicznej. Kontynuacje, t. II, przeł. S. Sikora, Warszawa, s. 119-138.

Rabinow P.

1999 Wyobrażenia sa faktami społecznymi: modernizm $i$ postmodernizm $w$ antropologii, w: M. Buchowski (red.), Amerykańska antropologia postmodernistyczna, przeł. J. Krzemień, Warszawa, s. 88-122.

2010 Refleksje na temat badań terenowych w Maroku, przeł. K.J. Dudek, S. Sikora, Kęty.

Rakowski T.

2011 Teren, czas, doświadczenie. O specyfice wiedzy antropologicznej po zwrocie krytycznym, w: T. Buliński, M. Kairski (red.), Teren w antropologii. Praktyka badawcza we współczesnej antropologii kulturowej, Poznań, s. 131-149.

Viveiros de Castro E.B.

1998 Cosmological Deixis and Amerindian Perspectivism, "Journal of The Royal Anthropological Institute", nr 4, s. 469-488.

2004a Exchanging Perspectives. The Transformation of Objects into Subjects in Amerindian Ontologies, „Common Knowledge”, nr 10 (3), s. 463-484.

2004b Perspectival Anthropology and the Method of Controlled Equivocation, „Tipiti”, nr 2 (1), s. 3-22. 